Studia Anglica Posnaniensia 50/1, 2015

doi: 10.1515/stap-2015-0017

\title{
IN DEFENCE OF THE TEXTUAL INTEGRITY OF THE OLD ENGLISH RESIGNATION
}

HELENA W. SOBOL

University of Warsaw

\begin{abstract}
Bliss \& Frantzen's (1976) paper against the previously assumed textual integrity of Resignation has been a watershed in research upon the poem. Nearly all subsequent studies and editions have followed their theory, the sole dissenting view being expressed by Klinck $(1987,1992)$. The present paper offers fresh evidence for the textual unity of the poem. First examined are codicological issues, whether the state of the manuscript suggests that a folio might be missing. Next analysed are the spellings of Resignation and its phonology, here the paper discusses peculiarities which both differentiate Resignation from its manuscript context and connect the two hypothetical parts of the text. Then the paper looks at the assumed cut-off point at 1.69 to see if it may provide any evidence for textual discontinuity. Finally the whole Resignation, seen as a coherent poem, is placed in the history of Old English literature, with special attention being paid to the traditions of devotional texts and the Old English elegies.
\end{abstract}

Keywords: Resignation, Exeter Book, Old English language and literature, textual studies, manuscript studies

\section{Introduction}

Resignation is preserved on fols. $117 \mathrm{v}-119 \mathrm{v}$ of Exeter Dean and Chapter MS 3501 (the Exeter Book), which dates back to the $2^{\text {nd }}$ half of the $10^{\text {th }} \mathrm{c}$. (cf. Ker 1957: 153). ${ }^{1}$ Since its first edition by Thorpe (1842), textual study of Resignation has inspired much research, culminating with the widely influential paper of Bliss \&

1 I would like to express my gratitude to both anonymous reviewers for their insightful remarks, which helped me to improve the paper. All remaining inaccuracies remain solely my responsibility. 
Frantzen (1976). There Resignation was for the first time argued to consist of fragments of two unrelated poems, with 1.69 - the last one on fol. $118 \mathrm{v}$ - forming the boundary between them. This theory was widely adopted by editors, such as Muir (1994) or Malmberg (1979), the latter also providing the first single-text edition of Resignation, and still the only one, according to my knowledge. A major dissenting view appears to have been expressed solely by Klinck in her paper (1987) and, especially, her 1992 edition of the Old English elegies.

The purpose of the present article is to re-examine Resignation for all possible evidence for its textual integrity. Klinck's research shall not be repeated here but added to, also through a different methodological approach. However, my disagreement with Bliss and Frantzen's conclusions could not prevent me from deep admiration of their work. Especially laudable is the inderdisciplinarity of their approach, achieved thanks to their broad knowledge and scholarly experience, together with the ingenuity of their ideas and their indubitable courage in advancing it. Throughout my own few years' research of Resignation I have tried to follow in their footsteps.

\section{Codicological evidence}

The text of Resignation is split between two gatherings, occupying the last two folios in gathering XV and the first of gathering XVI. Bliss and Frantzen argue for the loss of a folio between these gatherings, pointing to their irregular arrangement. As described by Förster (1933: 59), gathering XV (fols. 112-118) begins in a single sheet, which lacks a fold and hence is pasted to the fold of fol. 118, also a singleton. Gathering XVI (fols. 119-125) begins in two single sheets with folds pointing towards the right, and contains another singleton (fol. 124), whose fold appears after fol. 121 (see Fig. 1).

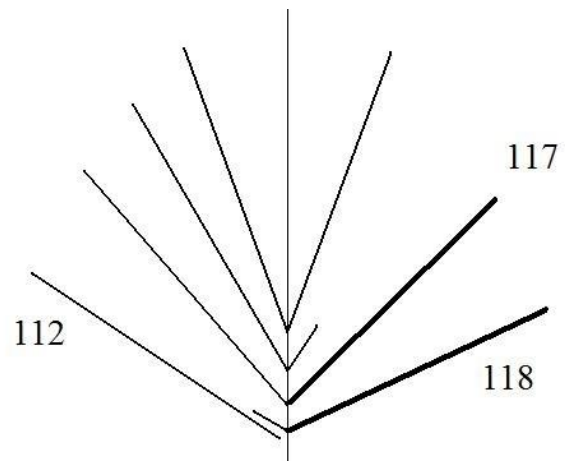

Gathering XV

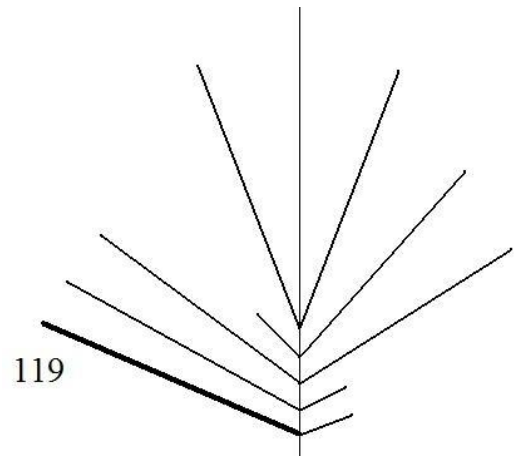

Gathering XVI

Figure 1. Diagrams of gatherings XV and XVI, based on Pickwoad (2006); the three Resignation folios (117-119) are marked with a thicker line. 
As Bliss \& Frantzen (1976: 387) observe, such an arrangement is both irregular and vulnerable, and hence would not have been intended originally. Hence they argue that fol. 112 is only the remaining half of a bifolium whose other half, now lost, used to occupy the place between the present fols. 118 and 119. This solution assumes for gathering $\mathrm{XV}$ the regular arrangement of singletons enclosed in protecting bifolia, analogous to that of gatherings II and VI.

However, the irregularity of gathering XV can be explained otherwise. The final of the 17 gatherings comprising the Exeter Book show progressing asymmetry due to damage and also to the high cost of vellum. Gathering XVII consists of five separate half-sheets pasted together, four of which originally formed two bifolia (after Förster 1933: 59; for a description of gathering XVI see above). Therefore other disruption patterns in this part of the manuscript may prove more plausible. Bliss and Frantzen disagree with an earlier solution, offered by Förster, who sees fol. 112 as the remnant right-hand half of an original bifolium inserted between gatherings XIV and XV. This hypothesis finds twofold support. First, Förster notes that since textual discontinuity confirms the loss of one folio - the last one in gathering XIV - possible is also the loss of yet another folio in the same place, i.e. the initial one of the hypothetical bifolium prefixed to gathering $\mathrm{XV} .{ }^{2}$ And second, as observed by Coveney (1958), the original plan of the Exeter Book was for every gathering to begin in the hair side of the vellum sheet, but $112 \mathrm{r}$ is the flesh side. If it had been part of an inserted bifolium, the terminal pages of the gatherings would have comprised only hair sides, because $112 \mathrm{v}, 113 \mathrm{r}$ and 118v are hair, as established by Muir (1989: 288). As has been shown, the condition of the manuscript does not offer positive evidence for any loss.

\section{Linguistic evidence}

The phonology and spelling of Resignation result from the combination of the Exeter Book scribe's native competence in Old English, influenced by his training, and the language of the poem's original composition. The number of presumable intermediate copies cannot be estimated, but these would also have transformed the text.

The spelling of Resignation conforms to most tendencies present in the manuscript. Nonetheless, two spelling features differentiate Resignation from its MS context. First, in the whole Exeter Book the only instance of the non-Late West Saxon form hio 'they' occurs at Resignation 1. 48, while elsewhere the scribe writes hilhy (also four times in Resignation: 11. 54, 55, and twice at 1. 57). ${ }^{3}$ And second,

2 No study seems to report any dating examination of the glue affixing fol. 112 to gathering $\mathrm{XV}$.

3 For evidence that Resignation 1. 48 hio represents the plural pronoun instead of the feminine 
Resignation 11. 24 and 70 provide two instances of wylle 'want' (pres. subj. sing.), whilst practically everywhere else in the MS the stem vowel character is $\langle i\rangle$ (twice so in Resignation: 11. 12, 104). ${ }^{4}$ As observed by Klinck (1992: 23), this characteristic not only differentiates the text from its MS context, but also unifies Bliss and Frantzen's Resignation A (i.e. 11. 1-69) with Resignation B (11. 70-118). Both the $3^{\text {rd }}$ p. pl. pronoun and the verb discussed above are high frequency words, which additionally strengthens the spelling evidence they provide.

Another spelling peculiarity of Resignation occurs in the two occurrences of sprecan 'speak' (also a relatively frequent word) at 11. 83b Forpon ic pas word sprcece 'Therefore I speak these words', and $97 \mathrm{~b}$ ond ymb sip sprcece 'and (I) speak about (my) journey'. As a strong verb, sprecan forms its preterite through ablaut: ic sprece 'I speak' vs. ic sprcec 'I spoke', a distinction preserved elsewhere in the Exeter Book. For both occurrences of $<$ spræce $>$ the context indicates unambiguously that the intended meaning is the present verb (ic) sprece 'I speak' and not the noun sprēece 'speech'. The spelling idiosyncrasy, though, most probably constitutes an example of the typically Northumbrian incorporation of the preterite vowel into the present form, described by Campbell (1959: $\S 327,743)$.

Klinck (1992: 18) suggested that yet another reflex of Northumbrian influence on Resignation may be found in the hypothetical loss of the final [n] in 1.21 cume (for cuman 'come', inf.) and 1.39 stonde (for stonden 'stand', pres. subj. pl.). If this loss was the result of a regularity in the phonological system of the scribe or his exemplar, we may expect to find other reflexes of this hypothetical regularity. As regards the stability of the final [n] in the whole Exeter Book, Muir (1994: 35) states that he abstains from emendation in all cases of (hypothetical) loss of a final nasal and provides two relevant examples, only one of them well-motivated, ChristA 1. 206 tirfruma[ $n]$ '(the) Author of glory, God' (acc. sing.). Nine more examples are offered by Malone (1930: 113-114), four of which are compelling: Seafarer 1.75 fremman for fremme 'perform' (pres. subj. sing.), OrW 1. 42 halge for halgan 'holy' (masc. acc. sing.), Wanderer 1. 102 hruse for hrusan 'ground' (acc. sing.), Rid 61.10 betan for bete 'make better' ( $1^{\text {st }}$ p. sing. pres. ind.). The available data is still too scant to prove an obligatory process of final [n] loss, or to provide a compelling argument for a Northumbrian influence upon the endings.

Nonetheless, the instability of final nasals could not be excluded if the scribe wrote $\langle-n>$ and $\langle-m>$ interchangeably, because such a tendency would indicate a loss of specification for the place of articulation. This loss constitutes part of

singular see below. The scribe also uses the form hie for 'they' in Christ 11.146 and 455 . The text of Resignation follows Klinck (1992), while all other Exeter Book poems are quoted after Muir (1994).

4 The third and last instance of wylle in the Exeter Book is Guthlac 1. 593. 
the levelling of endings, a weakening process which began to affect final, unstressed syllables of Late Old English and continued throughout the Middle English period. In unstressed syllables the vowel was reduced, while the final nasal lost its place specification and was deleted at a later stage, cf. Mitchell (1985: §§ 14-5), Quirk \& Wrenn (1955: § 13). Hogg (1992: § 7.102) notices only the change of the final $[\mathrm{m}]>[\mathrm{n}]$ in adjectives in the dative, whence he infers that at work is only the analogical spreading of the weak inflection -an, not phonological levelling. However, the Exeter Book data contradict this interpretation. Even though Riddle 601.15 contains an example concurrent with Hogg's analysis in twan for twam 'two' (dat.) in for unc anum twan cerendsprcece 'one message for the two of us', the MS provides two other instances for which Hogg does not account: freodon instead of freodom 'freedom' in The Lord's Prayer I 1. 10a ac bu us freodon gief 'but give us freedom', and cypam for cypan 'make known' in Judgement Day I 1. 103b Sop poet wile cypam 'Whoever may want to make known the truth'. Since the unetymological nasals occur word-finally, the spellings may result from levelling processes.

The beginning of the levelling of inflectional endings in the scribe's phonological system is further evidenced by his use of unetymological vowel letters in the unstressed, final syllables, e.g. Christ 1. 56 firina for firena 'sin' (gen.pl.). Muir (1994: 32-35) states that similar instances occur throughout the MS, albeit sparsely, for the scribe normalised his spelling to a great extent. Another argument for an active weakening process is the fact (observed by Klinck 1992: 14) that the majority of instances of swa peah 'nevertheless' in the Exeter Book, as also all three in Resignation (11. 29, 49, and 52), have been recorded in the form sepeah, preserved in no other MS. ${ }^{5}$ Since this adverb/conjunction always bears the stress on the second syllable, the form sepeah documents the reduction of the first, unstressed syllable.

The discussion of the weakening processes in the MS sheds some light on the relevant editorial problems of Resignation. As noted above, Klinck (1992: 191) argues for reading Resignation 1. 39 stonde as a levelled form of stonden 'stand' (pres. subj. pl.): Gesette minne hyht on pec, / forhte foreponcas, poet hio foestlice / stonde gestaðelad (11. 37b-39a) 'Set my expectation upon You, (my) fearful forethoughts, so that they would stand firmly established'. The subject of stonde, i.e. 1. 38 hio, cannot be the fem. sing. pronoun 'she' because the only sing. noun it might refer to would be 1.37 hyht 'expectation', which is always masc., and here modified by the unambiguously masc. acc. sing. minne 'my', cf. Klinck (1992: 191) and Bosworth \& Toller (1898). ${ }^{6}$ Therefore 1.38 hio can only be a $3^{\text {rd }}$ p. pl. pronoun 
which refers to 1.38 forhte foreponcas 'fearful forethoughts', and must take a plural verb. Since the context unambiguously refers to the future time, the verb stondan 'to stand' must be pres. pl., either the ind. stondad or the subj. stonden - both solutions assume the omission of a final letter, either $\langle\partial>|<\mathrm{p}>$ or $<\mathrm{n}\rangle$. As there was no process of final $[\theta]$ deletion, while a weakening in the final nasals seems plausible according to the discussion above, the loss of $\langle-n\rangle$ is decidedly more probable than that of $\langle-\delta>|<-p>$. Moreover, Mitchell (1985: $\S 2829)$ reports the subjunctive to be preferred over the indicative in clauses expressing a hypothetical result, and such is the case in the passage under consideration. Klinck $(1992: 18,191)$ suggests that the lack of a final $-n$ may also result from Northumbrian influence, a hypothesis additionally strengthened by the two occurrences of sprcece for sprece 'speak' $\left(1^{\text {st }}\right.$ p. sing. pres. ind.) in Resignation 11. 83 and 97, discussed above.

However, no persuasive motivation may be found for the other hypothetical omission of - $n$ suggested by Klinck (1992: 18, 189-190), Resignation 1. 21 cume for cuman 'to come'. Klinck reads Ic pa bote gemon, I cyninga wuldor, cuman to, gif ic mot (11. 20-1) 'I bear in mind the amendment, / oh Glory of kings (i.e. God), if I may come to it'. This interpretation assumes not only a levelled ending in cuman <cume>, which in itself would be possible phonologically. It also assumes that the speaker supposedly wants to base his knowledge of the amendment in the afterlife upon the condition that he could reach this afterlife, which seems unlikely. Indeed, the unemended MS cume can plausibly be read as subjunctive: Ic pa bote gemon, ... cume to, gif ic mot 'I bear in mind the amendment, ... I should come to it if I am able'. ${ }^{\text {? }}$

To conclude, Resignation has been shown to contain evidence of non-Late West Saxon influence in hio 'they' (nom.) at 1. 48 (Bliss and Frantzen's Resignation A). The influence may be further specified as Northumbrian due to the two instances of $\alpha$ for $e$ in sprcece 'speak' ( $1^{\text {st }}$ p. sing. pres. ind.) at 11.83 and 97, both in Resignation $B$. Another spelling characteristic of Resignation consists in the two instances of wylle 'want' (pres. subj. sing.) spelled with $<\mathrm{y}>$ at 11.24 (Resignation A) and 70 (Resignation $B$ ), which additionally differentiates the poem from its MS context. Thus dialectal and spelling features establish a linguistic connection be-

hihte 'in [the] hope' directly precedes holdre 'noble' (fem. dat. sing.). If holdre modified hihte 'hope' (dat. sing.) then hihte need also be fem. Yet this interpretation is rendered implausible by another occurrence of hiht at v. 9 of the same psalm, this time modified by the unambiguously masc. acc. gleawne 'wise'. Both Bosworth \& Toller (1898) and Toller (1921) provide numerous other examples of hyht/hiht in prose and verse, thus indicating that the word was in common use, but none rouses doubt as to the noun's masc. gender. Hence, double gender specification is implausible in this case, though it characterised some other Old English nouns, cf. Mitchell (1985: § $62 \mathrm{ff})$.

7 Another possibility would be to read cume as $1^{\text {st }}$ p. pres. sing. ind. 'I bear in mind the amendment, ... I (will) come to it when I am able'. 
tween Resignation $A$ and Resignation B, which constitutes one of the factors confirming the textual unity of Resignation.

\section{The cut-off point at 1.69}

As has been said, Bliss and Frantzen would divide Resignation at the end of 1. 69 . The editorial tradition prior to their paper presented $11.67 \mathrm{~b}-69$ as follows:

\begin{tabular}{ll}
\multicolumn{2}{c}{ Pe sie ealles ponc, } \\
meorda ond miltsa & para pu me sealdest. \\
No ðæs earninga & ænige wæron mid. (67b-69)
\end{tabular}

[Thank You for all the gifts and favours which You have given me. For these there was no merit (in me).]

Bliss \& Frantzen (1976: 389-390), however, object to such an arrangement on lexical and metrical grounds. They argue that 1.69 mid could not be used adverbially, as is assumed by traditional readings and in the translation above, because then it would have to be interpreted as 'with him, with it, with them, etc.', which they find unfit for the context. Hence, Bliss and Frantzen would place mid at the beginning of a new, incomplete line and posit an immediately following large gap in the text. However, Bosworth \& Toller (1898) and Toller (1921) quote many instances of adverbial mid, some of which parallel Resignation 1. 69b, e.g. Orosius p. 116 11. 26-27 in Sweet's (1883) edition: he his heres priddan doel gehydde, ond him self mid woes 'he hid the third part of his army, and himself was with (them)'. Furthermore, since the 1. 69 no ... earninga 'no ... merits' (nom.) can only belong to the speaker - the other possibility, God, is ruled out because $\mathrm{He}$ has all merits - the adverbial mid 'therewith' does fit the context, as in Thorpe's (1842) word for word translation 'for this not merits any were in me'.

Bliss \& Frantzen (1976: 390) offer also a metrical objection against the adverbial mid at the end of $1.69 \mathrm{~b}$. The only regular scansion of the half-line requires that woeron 'were' (pl.) be unaccented, which, however, violates Kuhn's law of sentence particles. The law states that unstressed elements such as finite verbs may be placed only before the second stress of the clause (a condition which is not fulfilled by the present context), otherwise they receive stress. Yet the whole poem contains numerous metrical irregularities; what is more, Mitchell (1985: $\S$ 3947) refutes the exceptionless applicability of Kuhn's law on syntactical grounds. Finally, Klinck (1992: 29) finds persuasive formulaic parallels between Resignation $A$ and Resignation $B$, such as the $X$ ealles ponc '[to someone] thanks for all' type of verse, occurring at 1.67 (Resignation $A$ ) and 1. 86 (Resignation B).

Thus, Resignation $1.69 \mathrm{mid}$ has been shown to fit both lexically and metrically without the need to posit any textual discontinuity at this point. 


\section{Literary analysis of Resignation as a coherent text}

The foregoing discussion has provided codicological and linguistic evidence for the integrity of Resignation. What remains to be shown is that, taken as a coherent text, the poem can be analysed without forcing any unnatural interpretation upon it. The discussion concentrates on two textual traditions which have been most often referred to in critical analyses of the poem: the so-called Old English elegies and the domain of prayer and devotion. A similarly directed attempt is to be found in Klinck's 1987 paper 'Resignation: exile's lament or penitent's prayer?', yet her methodology differs from that adopted in the following discussion. Klinck tries to deduce the poem's genre from a critical analysis of literary motifs present in Resignation and shared with other Old English elegies. Moreover, the critic largely disregards the Anglo-Saxon tradition of prayer, despite the adopted title. The following analysis, by contrast, concentrates rather on the structure of Resignation.

At this point a brief summary of the content of Resignation may prove helpful. The poem begins with an elaborate invocation to God, combined with pleas for His help, the gift of understanding, and steadfastness on the way to life eternal. Here, as also throughout the whole text, the speaker repeatedly admits his sinfulness and asks for remission. At ll. $41 \mathrm{ff}$ the speaker declares that his death is near and so prays that afterwards he may be taken to heaven by angels rather than to hell by devils. Afterwards, starting at 1.70 (the beginning of Resignation B), the general note changes from contrition to joyful hope and trust in God. This change, however, is short-lived, for at $11.77 \mathrm{ff}$ the speaker returns to the topic of his sinfulness, which he follows next (from about $1.83 \mathrm{~b}$ on) with the description of his sufferings, such as exile, poverty and dejection. The poem ends (1l. 117-118) with a maxim-like statement that one ought to bear one's fate well if it cannot be altered.

\subsection{Prayers}

Critics such as Noronha (1971) or Bliss \& Frantzen (1976) classify Resignation, especially its first part, among prayers. The prayer mode may be said to falter at 11. 70-76, where the speaker declares his hope and steadfastness right after yet another assertion of his unworthiness and sinfulness. The change of tone formed one of the major arguments for Bliss and Frantzen to regard 11. 70-118 as part of a separate text. This latter part of Resignation has major 'elegiac' features, discussed below. Here it ought to be stressed that the Old English elegies were by no means purely 'secular' works; very few medieval texts could be so described. On the contrary, the Old English elegies, most specifically The Wanderer and The Seafarer, meditate on the Christian attitude to hardships.

The multitude and diversity of devotional texts enriched Anglo-Saxon Christianity. The monks most of all had continual contact with the Bible - most 
notably the Book of Psalms - and the canonical prayers, which together formed the core of their beliefs and guided all religious thought. These texts were repeatedly translated, whole or in parts, into the vernacular and paraphrased into Latin and vernacular verse. The Bible and the liturgy also inspired the composition of many devotional texts in both languages, among them private prayers and various meditations, which could incorporate apparently secular topics into a main structure that was more overtly religious. At times, specimens of the latter group attain high artistic value, and so they constitute an apt background for the discussion of Resignation.

First and foremost it ought to be emphasised that the whole of Old English literature was copied by monks, and at least part of the extant poetry was also most probably composed by monks, because of its highly literate character, which would be unattainable without sound education. At that time all English monasteries adhered to the Rule of St. Benedict, extant are its numerous Anglo-Saxon copies, some of them glossed in Old English. Æthelwold, one of the chief proponents of the Benedictine revival in the latter half of the $10^{\text {th }} \mathrm{c}$., is credited with translating the Rule into Old English. Chapters VIII-XIX of the Rule describe the precise shape in which monks were to perform the Divine Office. Both the Latin and the Old English version of the Rule agree that, except for Nocturns (the only night-time office, said between midnight and daybreak) and festal days, every canonical hour had to begin with Ps 70 [69]: 2 Deus, in adiutorium meum intende; / Domine, ad adiuvandum me festina 'God, come forward to my rescue; Lord, hasten to help me'. Such is the beginning of prayers said seven times daily by monks, and Resignation commences with strikingly similar words: Age mec se celmihta god! / Helpe min se halga dryhten! 'Let the almighty God hold me in His keeping! Let the holy Lord help me!'. ${ }^{8}$ Admittedly, this is no direct translation of the Psalm versicle. Yet the fact that a double plea for God's help begins a text, calling God first as god 'God' (cf. Deus in the Latin) and then as dryhten 'Lord' (cf. Domine), points to a clear and most probably intentional connection between Resignation and the Divine Office.

Secondly, the canonical prayers constituted the core of Christian devotion. The Lord's Prayer and the Creeds played a major role in Anglo-Saxon Christianity, as they have done so to this day. Bede, Ælfric and Wulfstan repeatedly exhorted priests to teach these texts to the laity and explain them often, as expositions of the fundamental tenets of faith with the authority of God the Son and His Apostles.

8 The first word of Resignation, Age, poses difficulties as to its meaning. Literally Age mec means something like 'let ... own me, let ... possess me', clearly not the sense intended in the present context. A satisfactory reading for Resignation 1. 1 has been offered in Cameron, Amos \& Healey (2003), under āgan, I.A.9.a, 'of a protector or patron: to hold (someone) in one's keeping'. This reading additionally corroborates the textual link with the Divine Office argued for in the present paper. 
They also translated the prayers into vernacular for the benefit of the laity and uneducated clergy; extant translations were composed for instance by Ælfric and Wulfstan. The Lord's Prayer and the Creed, as well as other liturgical texts, were also paraphrased in Old English verse. ${ }^{9}$

Echoes of two canonical prayers may be discerned in the text of Resignation: the Lord's Prayer and the Creed. Thematic parallels with the Pater noster occur at 11. 19-20a Forgif me to lisse, lifgende god, / bitre bealodoede 'mercifully forgive me, living God, (my) bitter and wicked deeds', expressing a plea similar to $E t$ dimitte nobis debita nostra 'And forgive us our trespasses'. Similarly, 11. 26b-28 Feorma mec, hwoepre, I meotod, for pinre miltse, peah pe ic ma fremede I grimra gylta ponne me god lyfde 'Yet receive (or: sustain) me, Measurer, for Your mercy, even though I have committed more crimes than God allowed me to' are reminiscent of Panem nostrum quotidianum da nobis hodie: Et dimitte nobis debita nostra 'Give us this day our daily bread. And forgive our trespasses'.

Furthermore, the opening words of Resignation resemble not only parts of the Divine Office, but also of the Apostles' Creed, which begins with Credo in Deum Patrem omnipotentem, Creatorem caeli et terrae 'I believe in God, the Father almighty, Creator of heaven and earth'. In the characteristics attributed to God this statement is reminiscent of the two initial lines of Resignation: Age mec se celmihta god! I Helpe min se halga dryhten! Pu gesceope heofon ond eorpan 'Let the almighty God hold me in His keeping! Let the holy Lord help me! You have created heaven and earth'. Lexical similarity becomes more clearly visible once the Resignation lines are compared to Ælfric's translation of the Apostles' Creed: Ic gelyfe on God, Fader Almihtigne, Scyppend heofonan and eorðan, which chooses the same words as the Resignation poet (the quotation from Ælfric follows Thorpe 1846, 596). In both Resignation and the Creed God is declared celmihtig 'almighty' (though, again, Resignation has celmihta god 'almighty God' which the Creed expands to God, Foeder AElmihtig 'God, almighty Father'), He has created (gesceope, Resignation) or is the Creator (Scyppend - a noun with the same stem as gesceppan 'to create', Creed) heaven and earth (heofon ond eorðan, both texts).

Let us now turn to the poetic paraphrases of the canonical prayers. Bliss and Frantzen would classify Resignation A with the Old English verse paraphrases of liturgical prayers, such as the Lord's Prayer I, II and III, Gloria I and II or the metrical Psalms. These cannot bear any structural similarity to Resignation since the latter does not paraphrase any specific liturgical prayer (or prayers). Admittedly, some similarity may be found in vocabulary, especially the great variety of

LPr I is printed in Muir (1994); the Paris Psalter in Krapp (1932); and all the others in Dobbie (1942). Except for the Psalms, the texts referred to in the present note have been newly edited in Keefer (2010), but all quotations in the present paper follow the older editions, because Keefer renumerates lines so as to count in Latin prose, which was not the practice of standard editions and hinders any clear reference. 
often complex and metaphorical expressions for God. ${ }^{10}$ The stock of the vernacular nomina sacra had resulted from the centuries-long development of the Anglo-Saxon Christian culture, which had infused the Germanic culture with the Christianity of Rome and its learning, at the same time striving to express it all in the native language and its literary tradition. A few of the most common titles which also occur in Resignation, for instance god 'God', dryhten 'Lord', meotud 'Measurer' or frea 'Lord', appear throughout the corpus of Old English verse. Certain other, more complex names are used in more than one poem, e.g. Resignation 1. 19 and LPr II 1. 101 lifgende god 'living God', Resignation 1. 63 and Glor I 11. 17, 22 ece god 'eternal God', Resignation 11. 41, 62 and LPr III 1. 1 foeder moncynnes 'Father of mankind'. Resignation 1.1 oelmihta god 'almighty God' constitutes a variant of the commonly used title celmihtig god.

Of all extant Old English verse paraphrases of liturgical prayers the Kentish Psalm 50 shares with Resignation the most epithets for God, though still few in number. It contains not only the generally frequent oelmehtig god (11. 33, 85), moehtig dryhten 'mighty Lord' (1. 62, cf. Resignation 1.61 mihtig dryhten 'mighty Lord'), faeder mancynnes 'Father of mankind' (1. 110, Resignation 11. 41, 62) or god lifigende 'living God' (11. 112, 134, cf. Resignation 1.19 lifgende god); but also the rarer liohtes hiorde 'Shepherd of light' (1. 101, cf. Resignation 1. 8 leohtes hyrde 'Shepherd of light'). Moreover, from among the Old English liturgical verse only KtPs 50 and A Prayer surpass Resignation in the diversity and ingenuousness of nomina sacra. ${ }^{11}$ The large number of invocations of God's name might have led Klinck (1992: 56) to criticise the first part of Resignation for its presumable repetitiveness. However, this may have resulted from the critic's rather strict elegiac classification of Resignation. While constant repetition of prayerful invocation of God's name may constitute a fault in an elegy, it need not be one in a religious poem which addresses God.

The great profusion of various nomina sacra in A Prayer forms elaborate rhetorical patterns, which are generally absent from Resignation, cf. Keefer (1998: 3043). Nevertheless, the two poems resemble each other to a certain degree, as in both of them confessional elements constitute major topics. A Prayer begins with three similarly constructed verse paragraphs, which first invoke God and then ask for mercy and divine grace: 1.2 geara me 'have mercy upon me', 11. 9-10 gemiltsa pyn mod me to gode, / sile pyne are pinum earminge 'make mild Your heart for my benefit, give Your grace to Your miser', 11. 22-24 getipa me ... ece are 'grant me eternal grace'. ${ }^{12}$ Other typically confessional motifs present both in Resignation

10 For a comprehensive study of nomina sacra in Resignation A cf. Gretsch (2008: 105-9).

11 The text of $A$ Prayer follows Keefer (2010).

12 Keefer (2010: 226) interprets 1.2 geara as imp. sing. of gearwian 'make ready', but the regular imp. sing. form of this verb is gearwa. On the other hand, geara constitutes the regular imp. sing. of gearian 'to honour; to have mercy'. The latter verb fits the context better than 
and in A Prayer are repeated acknowledgements of the speaker's sinfulness, plea for help in doing God's will ( $\operatorname{Pr}$ 1l. 71-2 gefylste me ... poet ic pinne willan gewyrcean moege 'help me so that I may do Your will') and for eternal joy in heaven.

The prayerful passages of Resignation display also other, more pronounced confessional features, clearly visible when the poem is compared to the Confiteor. The most conspicuous textual link between the two consists in the fact that both texts enumerate 'thoughts, words and works'. This parallel remains valid even though the list plays different roles in the two texts: while in the Confiteor a penitent confesses: peccavi nimis cogitatione, verbo et opere 'I have greatly sinned in my thoughts, words and works', the Resignation speaker offers these to God:

Ic pe, mære god,

mine sawle bebeode ond mines sylfes lic, ond min word ond min weorc, witig dryhten, ond eal min leopo, leohtes hyrde, ond ba manigfealdan mine gepohtas. (5b-9)

[I offer to You, great God, my soul and my own body, and my words and my works, wise Lord, and all my limbs, Shepherd of light, and my manifold thoughts.]

The second major confessional characteristic of Resignation is that the speaker repeatedly admits his sinfulness and appeals to God's mercy - a motif which additionally connects the poem's two parts posited in Bliss and Frantzen. Thus, the following instances occur in Resignation A: 11. 16-18 peah pe ic scyppendum ... waccor hyrde ... ponne min raed weere 'although I have been more weakly hearkening to the Creator than I should have', 11. 26b-28 (above), 11. 51b52a peah de ic mana fela / after dogrum dyde 'even though I have committed many crimes during (my) days', 11. 64b-65a Min is nu pa / sefa synnum fah 'now my mind is guilty of sins'. Resignation $B$ furnishes more examples: $11.78 \mathrm{~b}-79 \mathrm{a}$ Gode ic habbe / abolgen, brego moncynnes 'I have angered God, the Ruler of mankind', or 11. 108-110 Eala, dryhten min ... paet ic eom mode [s]eoc, bittre abolgen 'Oh, my Lord, bitterly angered because I am sick at soul (i.e. sinful)'. ${ }^{13}$

Generally speaking, prayer themes dominate Resignation; hence it has been compared to various Latin and Old English prayers and hymns. Accordingly, Bestul (1977) places the poem among private confessional prayers found in insu-

the former, for it allows for the triple plea for grace described above, which is expressed each time by words built on the stem ar 'honour; mercy, grace', present in gearian, and 11. 10, 22 are 'grace' (acc. sing.). This stem is absent from gearwian 'make ready', a verb built on the stem gearu 'ready'.

13 For the latter meaning cf. Bosworth \& Toller (1898), seoc, adj. II. 
lar manuscripts dating back to the $8^{\text {th }}-10^{\text {th }} \mathrm{c}$., for several such texts contain thematic similarities to Resignation. An especially apt Latin example may be found in prayer 10, entitled Alma confessio 'Nourishing confession' (first singled out for comparison with Resignation in Stanley 1955: 451), from the Book of Cerne, i.e. Cambridge, University Library MS Ll.1.10, a prayerbook dating back to the $1^{\text {st }}$ half of the $9^{\text {th }}$ c. ${ }^{14}$ Kuypers (1902: xxiv-xxv) notes that Alma confessio is most probably of Irish origin and belongs to a type of confessional prayer which provide an extremely wide catalogue of sins whose purpose was for everyone to feel included together with their specific sins and also to arouse repentance. ${ }^{15}$ The prayer begins by calling God 'almighty': Deus deus meus omnipotens 'God, my almighty God' - a prayerful element shared by Resignation 1.1 Age mec se celmihta god 'Let the almighty God hold me in His keeping'. Then it asks for forgiveness of sins and emphasises their immense number: Ego te peto remisionem omnium peccatorum ... Multiplicata sunt debita mea super me quia peccata mea numerum non habent 'I ask You for forgiveness of all sins ... My sins have been multiplied against me, because my sins are innumerable'. The motifs appear in Resignation for instance in 11. 19-20a (above), 11. 25b-26a Nu pu const on mec / firendceda fela 'Now You know in me many wicked deeds', or 11. 76b-78a Huru me frea witeð / sume para synna pe ic me sylf ne conn / ongietan gleawlice 'However, the Lord knows in me some sins which I myself cannot perceive clearly', which possibly implies their immense number. Lastly, Alma confessio asks God: doce me quid debeam agere 'teach me what I ought to do', and a plea to the same result occurs in Resignation 11. 10-12:

Getacna me, tungla hyrde,

pær selast sy sawle minre

to gemearcenne meotudes willan. (10-12)

[Show me, Shepherd of stars, where it would be best for my soul to observe the Measurer's will.]

Since all of the themes mentioned in connection with the Latin prayer are typical for confessions, their presence in Resignation points to the poem's confessional character.

Bestul (1977: 21) and Noronha (1971: 30) agree that closer parallels may be found among Old English confessional prayers. One of these provides passages remarkably reminiscent of Resignation; it is preserved on fols. $104 \mathrm{r}-105 \mathrm{v}$ of the British Museum MS Cotton Galba A. xiv, which dates back to the $1^{\text {st }}$ half of the $11^{\text {th }} \mathrm{c}$. and contains prayers, recipes and a book of private devotions, mainly in

14 For dating of the Book of Cerne cf. Kuypers (1902: xi-xiii), and Brown (1996: 162-164).

15 Text of Alma confessio printed after Kuypers (1902: 95-99). 
Latin. ${ }^{16}$ Banks (1968: 526-529) describes this prayer as a free elaboration of liturgical material, opened and closed by liturgical formulae, and regularly employing alliteration and rhythm. A passage especially closely resembling the beginning of Resignation occurs at the beginning of the prayer: ${ }^{17}$

In naman $\mathrm{b}[$ ære hal $]$ gan prynesse, pæt is fæder, and [sunu and] se halga gast, god ælmihtig. Pam ic eo[m and]etta ec[ne], ælmihtigne god a wesendne, and a wuniendne to widan feore.

Pam ic bebiode minre sawle gehealdnesse and mines lichoman, min word and weorc and mine gepohtas, mine heortan and minne hyge, min leomu and mine lioðu. $(1-10)$

[In the name of the Holy Trinity, that is the Father and the Son and the Holy Spirit, almighty God. To Him I acknowledge an eternal, almighty God, always existing, and always everlasting. To Him I offer the custody of my soul and of my body, my words and my works, and my thoughts, my heart and my mind, my limbs and my joints.]

Apart from the designation of God as god celmihtig 'God almighty', which occurs here twice, in 1l. 3 and 4, the following dedication to Him (11. 6-10) of the speaker's soul, body, words, works, thoughts and limbs corresponds almost exactly to 11. 5-9 of Resignation (quoted above). The dedication employs nearly the same vocabulary as in Resignation: ic bebiode 'I offer' (cf. Resignation 1. 5-6 ic bebeode), minre sawle 'my soul' (gen., Resignation 1.6 mine sawle, acc. sing.), mines lichoman 'my body' (gen., Resignation 1.6 mines sylfes lic 'my own body', acc.), min word and weorc 'my words and works' (acc., Resignation 1.7 min word ond min weorc 'my words and my works', acc.), mine gepohtas 'my thoughts' (acc., Resignation 1. 9 pa manigfealdan mine gepohtas 'my manifold thoughts', acc.), min leomu and mine lioðu 'my limbs and my joints' (acc., Resignation 1.8 eal min leopo 'all my limbs'). The Cotton Galba prayer continues the enumeration of offered items, yet the beginning of the list, quoted above, is identical to that in Resignation.

16 Cf. Ker (1957: 198), and Braekman (1965: 271).

17 This prayer has been tabulated among many others for comparison with Resignation in Noronha (1971: 31-33), but without noticing the outstanding character of its similarity to the poem. Bestul (1977: 21) mentions the MS, yet only with regard to its Latin contents. The prayer's text and layout follows Braekman (1965: 272-273), who preserves the MS layout, but the punctuation has been changed into the Modern English system (the editor preserves the MS punctuation). 
The prayer provides one more, minor similarity to Resignation, which occurs towards the end of fol. 104v: and purh his paet halige godspell and eal pa wundor pe poer on syn 'and through His holy Gospel and all the wonders which are therein'. The second part of the passage closely parallels Resignation $11.2 \mathrm{~b}-4 \mathrm{a}$ $P u$ gesceope heofon ond eorpan, ond wundor eall ... paer on sindon 'You have created heaven and earth, and all wonders ... (which) are therein'. The textual parallels between Resignation and the Cotton Galba prayer are of an almost verbatim nature, although they consist of frequently used formulas. More importantly, however, common major topics occurring both in Resignation and in certain prayers form a strong argument for the prayerful character of the poem.

Summing up, Resignation contains pronounced structural, thematic and linguistic parallels to the various prayers discussed above. Typologically the poem most closely resembles penitential prayers, especially the one from the Cotton Galba MS, as well as A Prayer. Indeed, Resignation could have been regarded as a prayer in the vein of A Prayer but for its elegiac passage and the final maxim, which prescribes endurance without an explicit reference to God.

\subsection{Elegies}

Rather surprisingly in the context of the above, prevailing scholarly opinion classifies Resignation among the so-called elegies, a group of nine Exeter Book poems: The Wanderer, The Seafarer, The Riming Poem, Deor, Wulf and Eadwacer, The Wife's Lament, Resignation, The Husband's Message, and The Ruin. The fact that they have been gathered in a single manuscript may suggest generic affinities between the poems although they are interspersed with various other material. Thus, Wanderer and Seafarer are separated by two wisdom poems in catalogue form, The Gifts of Men and Precepts, while Riddles directly follow and precede the more obscure Wulf, Wife and Husband. Moreover, the MS layout of Husband suggests three separate texts rather than one - possibly a mistake caused by the poem's enigmatic character and the presence of runes at its end. Some of the nine Old English poems first began to be called 'elegies' in the early $19^{\text {th }} \mathrm{c}$., although none of them approaches to the classical elegiac metre or laments the dead. ${ }^{18}$ Yet another meaning of the term 'elegy' was introduced during the Romantic period: sentimental, meditative and personal poetry on any subject. The modern word fitting such a definition would be 'lyric', and this is how Schlauch (1956: 65-9) chooses to classify the poems, adding that they share their elegiac themes with Beowulf 11. 2247-66 ('Lament of the last survivor') and 2444-62 ('Lament of the father'). Dissent from classifying the Old English texts as elegies was also ex- 
pressed by Bloomfield (1970: 77-80), who subsumes them into the larger category of wisdom literature.

Nevertheless, certain basic similarities in language, content and structure do exist between these nine texts, Resignation included, though most definitions of the Old English elegy are imprecise. Possibly the most coherent definition was offered by Greenfield (1966: 214), who recognises three major characteristics: 'a contrast between past and present conditions', 'some awareness of the transitory nature of earthly splendour, joy, and security', and 'a pattern of loss and consolation'. This description is so broad as to fit, for instance, a saint's life or a psalm paraphrase, though it does capture important generalisations. Nearly all of the elegiac characteristics of Resignation are to be found in the poem's final part, beginning at about 1.83 .

The foremost reason for considering Resignation as an elegy lies in the poem's repeated mention of a fearful journey, hardships and exile. The 'elegiac' readings of Resignation emphasise especially 11. 89b-91a:

Forpon ic afysed eom
earm of minum eple. Ne mæg pæs anhoga,
leodwynna leas, leng drohtian,
wineleas wræcca. (89b-91a)

[Therefore I am ready to depart, poor, away from my home. Because of that the solitary one, without social joys, cannot live long, the friendless exile.]

Here the typically elegiac motif of exile is expressed vocabulary which frequently occurs in the elegies, though is not confined to them. The most common element of the motif is wraecca 'person in exile, wretched person', also in the phrase wineleas wrecca 'friendless exile', which describes the speaker of Wife in 1.10 and Cain, an outcast from God, in Genesis 1. 1051, cf. Klinck (1992: 228). Wretchedness and spiritual exile can also take other forms, such as the sufferings of the fallen angels in Resignation 1. 58 wroece (fem. acc. sing. or pl.), or the laming and captivity of Weland in Deor 1.1 wrceces (neut. gen. sing.) and 1.4 wraece (fem. acc. sing. or pl.). The course of misery may be the Wanderer's and the Seafarer's wrceclastas 'paths of exile' (Wanderer 11. 5, 32; Seafarer 11. 15, 57), the wroecface 'time of misery' in Riming Poem 1. 64, or the wroecsipas 'times/places of exile/misery' lamented by the speaker in Wife (1l. 5, 38). ${ }^{19}$

Despite hardships, the Resignation speaker longs for his journey, thus resembling the Seafarer. This longing is expressed by ic afysed eom 'I am ready to

19 The lexical morpheme -sip/-sið in compounds such as wraecsip has two basic meanings, 'journey' and 'time', with precise differentiation impossible at times. Hence here and below lexical glosses give both readings whenever the precise meaning cannot be established beyond doubt. 
depart' in Resignation 1. 89 (above) and again at 11. 97b-98: ond ymb sip sprcece, / longunge fus, ond on lagu pence 'and (I) speak about the journey, / eager with longing, and think about the sea'. The latter bears close thematic and lexical similarity to Seafarer 1. 47: ac a hafad longunge se pe on lagu fundað 'but he always has longing who hastens towards the sea'; both speakers are fus 'ready/eager to depart': Resignation 1. 84 fus on ferpe 'with a soul eager to depart', Resignation 1. 98 (above), and Seafarer $1.50-52:{ }^{20}$

ealle pa gemoniað modes fusne sefan to sibe, pam pe swa penceð

on flodwegas feor gewitan. (50-52)

[all these remind the spirit with a mind eager to depart upon a journey, one who thus intends to set out far away towards the sea.]

Longing is a recurrent theme in the elegies, especially prominent in Wife, where the speaker's painful yearning for her husband constitutes the main topic; an apparently similar longing for her beloved Wulf is expressed at some length by the speaker of Wulf. Resignation also mentions other kinds of hardship which it shares with some elegies. Thus, friendlessness, noted above for 1. 91, reappears at 1. 102, where it combines with poverty and hinders his journey:
Nah ic fela goldes,
ne huru pæs freondes pe me gefylste
to pam siðfate, nu ic me sylf ne mæg
fore minum wonæhtum willan adreogan. (101b-104)

[I do not have much gold, nor even a friend who would help me go on the journey, by myself now I cannot perform the will because of my scanty possessions.]

Poverty does not impede the speaker's appointed journey in any other elegy. Thus, in Ruin and Wanderer absent riches serve as a means of bitter contrast between past splendour and present desolation. On the other hand, Seafarer invokes the problem of present wealth in 11. 66b-67 and 97-102, which discuss the uselessness of earthly riches for attaining eternal life. ${ }^{21}$ The two different ways of

20 It ought to be noted that the motifs of journey and exile frequently play a major role in literary treatments of the theme of pilgrimage. At that time 'pilgrimage' meant not only travelling to holy places, but also travelling to foreign lands, far away from home - an ascetic practice helping one in the search for God (Whitelock 1950). The latter practice was characteristic of the early Irish Church, whence it came to Anglo-Saxon England together with numerous other Christian traditions.

21 Sisam (1945) argues convincingly that Seafarer 1l. 97-102 were inspired by Ps 49 [48]: 7-9, 12, 18. 
introducing the theme of wealth in Seafarer and Resignation in relation to journeys undertaken most probably for religious reasons complement each other. If Seafarer argues for renouncing one's possessions in the spirit of peregrinatio pro amore Dei 'pilgrimage for the love of God', Resignation may be seen to advocate absolute reliance on Divine Providence when performing God's will. ${ }^{22}$

Another widely recognised feature of the elegies is the $1^{\text {st }}$ person singular introduction to a speech. It is to be found for instance in Wanderer 1l. 8-9a Oft ic sceolde ana uhtna gehwylce / mine ceare cwipan 'Often alone I had to tell my sorrows before each dawn'. Seafarer 1l. 1-2a offer another instance: Moeg ic be me sylfum soðgied wrecan, / sipas secgan 'May I make about myself a true song, tell about journeys/times'. To the latter Wife 1l. 1-3a bear close lexical similarity:

Ic pis giedd wrece bi me ful geomorre, minre sylfre sið. Ic pæt secgan mæg, hwæt ic yrmpa gebad (1-3a)

[I make this song about myself, very sad, about my own time. I can tell which miseries I have experienced]

In Resignation such a construction is used twice, at 11 . 83b-85a: Forpon ic pas word sprace, I fus on ferpe, swa me on frymðe gelomp / yrmpu ofer eorpan 'Therefore I speak these words, with a soul eager to depart, about how at the beginning happened to me misery on earth', and 11. 96b-98a: Ic bi me tylgust I secge pis sarspel, ond ymb sip sproce, / longunge fus 'I say this lament about myself most strongly, and speak about the journey, eager with longing'. A distinguishing characteristic of the speech introductions in Resignation is that both occurrences contain the adjective fus 'ready to depart', referring either to physical journey or to the journey of death. Raw (1978: 127) notes the prominence of the latter meaning in Resignation, and her argument receives additional support from the fact that Resignation 11. 41-43 state explicitly that the speaker hastens away from this world and towards God, while $11.49 \mathrm{~b}-53$ ask God to let angels take the

22 For a study of the concept of peregrinatio pro amore Dei cf. Whitelock (1950). A parallel situation may be found in Andreas. God orders St Andrew to travel and preach His word, despite his lack of seafaring friends (11. 198b-201) or money (11. 271-6, 301-4). Andreas obeys, goes to the nearby harbour and receives a generous welcome on board by a captain God Himself in disguise. Such reliance on Divine Providence derives from Christ's command (paraphrased in Andreas 11. 332-9), Matthew 6: 31-33 'Therefore take no thought, saying, What shall we eat? or, What shall we drink? or, Wherewithal shall we be clothed? ... [F]or your heavenly Father knoweth that ye have need of all these things. But seek ye first the kingdom of God, and his righteousness; and all these things shall be added unto you.' and 28:19-20 'Go ye therefore, and teach all nations ... [t] eaching them to observe all things whatsoever I have commanded you' (both quotations from King James Version). 
speaker's soul to Him rather than devils - to hell. Thus the recurrent use of fus in the speech introductions in Resignation puts additional emphasis on the symbolic aspect of the journey motif.

Yet another commonly recognised feature of the elegies concerns the thematic structure of the whole texts: Greenfield's (1966: 214) 'pattern of loss and consolation' or, more broadly, Klinck's (1992: 246) 'move[ment] from disquiet to some kind of acceptance'. Some elegies do not fit this pattern explicitly, e.g. Wulf, Wife, and Ruin offer no overt consolation. The pattern develops most prominently in Wanderer, Seafarer and Riming Poem. ${ }^{23}$ The major part of both Wanderer and Seafarer describes their personas' miseries, occasionally interrupted by maxims or religious admonitions. In both poems the topic gradually changes from the fate of a presumably specific speaker to that of a human being in general. Wanderer ends with a maxim about discretion, followed by a similarly constructed statement about the prudence of seeking mercy and help from God (11. 112-115). On the other hand, the author of Seafarer ends his poem with a rather long homiletic passage concerning the fear of the Lord, steadfastness and the eternal bliss in heaven (11.103-124, perhaps beginning even earlier, at 1.97 or 94 - the transition between the two parts is gradual). Yet another way of implementing the pattern may be observed in Riming Poem, where the initial description of prosperity in 1l. 3-42 precedes the 'elegiac' $11.43-79$, which narrate the downfall of the speaker's good fortune. This is followed by the homiletic ending in 11. 80-87, which reminds the audience about the eternal bliss in heaven and the ways of reaching it. When compared to the above, Resignation may be also seen to implement the pattern, for the poet places the 'elegiac' part (11. ca. 83-116) between a prayer to God and the final maxim-like statement Giet bið poet selast, ponne mon him sylf ne moeg / wyrd onwendan, poet he ponne wel polige (11. 117-8) 'Yet it shall be best, when one cannot by himself change his fate, that he should suffer it well'.

Klinck (1992: 225-227) agrees that the pattern is discernible in Resignation, but believes that 11. 117-118 constitute a maxim about mundane endurance of earthly hardships - for so they appear if dislodged from the context of the entire poem. The greater part of Resignation consists of a prayer to God for help, understanding, a remission of sins with hope for heaven, intermingled with acts of contrition. Yet crucial for the interpretation of the poem's ending are 11. 64b-76a. In 11. 64b-69 the speaker again expresses his sinfulness and thanks God for all His unmerited graces; next he declares:

23 It is also prominent in Deor, but in a unique form. Each of the poem's six stanzas is followed by the refrain Paes ofereode, pisses swa moeg 'That was overcome, so may this', which participates in the consolation motif. Yet the motif also develops through the poem's structure: the five initial stanzas deal with great sufferings of historical and legendary personages. The speaker, Deor, may find consolation in the consciousness that famous people also experience great hardships. Additionally his own suffering may seem diminished. 


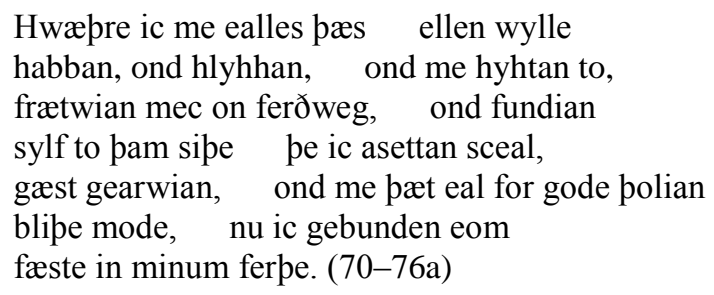

[Nevertheless I want to have all the courage and laugh, and have hope, and adorn myself for the way of the spirit, and hasten myself to the journey which I must make, prepare my soul, and suffer it all for God with a joyful mind, now I am bound fast in my spirit.]

In light of this passage 11. 117-118, which follow all the narration of the speaker's sufferings, recapitulate the steadfast and hopeful attitude expressed earlier. Thus, Resignation makes use of the pattern of loss and consolation' in its elegiac part, for the description of miseries directly precedes the final, consoling maxim.

\section{Conclusion}

The most crucial conclusion pertains to the problem of Resignation's textual integrity, which was rejected by Bliss and Frantzen. First of all, no codicological description of the Exeter Book appears to provide conclusive evidence for the loss of a folio in between the pages preserving Resignation, and all MS irregularities can be explained otherwise. Moreover, the last word on fol. 118v, Resignation 1.69 mid, can take the adverbial meaning 'therewith', which fits the context without the need to assume any textual disunity at this point. Spelling and linguistic features also show that the poem comprises a single text. Thus the non-LWS influence mentioned above connects Resignation A and Resignation B, with hio 'they' at 1.48 (Resignation $A$ ) and <spræce> for sprece ' $[\mathrm{I}]$ speak' at 11.83 and 97 (Resignation B). These dialectal features also distinguish Resignation from the neighbouring texts, as do the two occurrences of wylle 'want' (pres. subj. sing.) at 11.24 (Resignation A) and 70 (Resignation $B$ ) - a common word whose otherwise regular form is wille. Finally, Bliss and Frantzen point to the thematic difference between Resignation $A$ and $B$, observing that Resignation $A$ constitutes a confessional prayer, while Resignation $B$ - an elegiac lament. Yet the typically elegiac features of Resignation do not begin before 1.83 , and still the elegiac passage contains prayerful elements, such as 1.86 gode ealles ponc 'thanks be to God for everything' or 11. 108b-111a:

\footnotetext{
Eala, dryhten min,

meahtig mundbora, pæt ic eom mode [s]eoc,

bittre abolgen. Is seo bot æt pe

gelong æfter [li]fe. (108b-111a)
} 
['Oh, my Lord, mighty Protector, bitterly angered because I am sick at soul. The remedy belongs to You, after life.']

The prayer mode prevails in the whole poem. It is especially emphasised by an invocation of God and plea for His help prominently situated at the beginning. Names for God, often elaborate, abound in Resignation in a similar manner to certain verse prayers, such as the Kentish Psalm 50 or A Prayer. The poem contains major confessional features, for instance in the repeated admission of the speaker's sinfulness, pleas for God's mercy, or the cogitatione, verbo et opere formula. A close, hitherto nearly overlooked parallel to Resignation may be found in a prose confessional prayer from the British Museum MS Cotton Galba A. xiv. Hence, the poem belongs to the general tradition of Christian confessional prayer, sharing also a few motifs with the canonical prayers.

From about 1.83 till the end (1.118) Resignation approaches to an Old English elegy. Structurally, this may be seen in the presence of a $1^{\text {st }} \mathrm{p}$. speech introduction at the beginning of the elegiac passage, and of Greenfield's 'pattern of loss and consolation'. More prominent are the common elegiac motifs, such as the loneliness of exile and a fearsome journey full of hardships. However, elegy cannot dominate Resignation because of the placement of the relevant passage towards the poem's end, and its relative shortness. ${ }^{24}$

A reviewer points out that the paper has failed to address the issue of the relative literary quality of Resignation's major parts, even though this may constitute a significant factor in the discussion of the poem's integrity. Indeed, scholarly opinion (almost) unanimously credits the 'elegiac' fragment with literary value far exceeding that of the prayerful majority of Resignation. The sadness and steadfastness in face of hardships expressed in the second part of the poem speak powerfully to the modern audience, including the present author. Yet it must be recognised that also the first part of Resignation contains passages of great beauty. For instance, the highly imaginative pair of God's titles, 1.8 leohtes hyrde 'Shepherd of light' and tungla hyrde 'Shepherd of stars', the latter uniquely occurring in Resignation. Equally impressive are passages of grammatically and logically parallel structures, such as the opening lines 1-2 Age mec se celmihta god! / Helpe min se halga dryhten!, the Confiteor-like declaration that follows, or the first mention of a long journey, 1l. 41-43 Nu ic fundige to be, faeder moncynnes, / of pisse worulde, nu ic wat paet ic sceal / ful unfyr faca 'Now I hasten to You, Father of mankind, away from this world, now I know that I must go before long'. Admittedly, the assessment of literary quality depends on a critic's personal preferences to a considerable extent; hence the present paper leaves the matter open. 


\section{REFERENCES}

\section{PRIMARY SOURCES}

Braekman, Willy. 1965. Some minor Old English texts. Archiv für das Studium der neueren Sprachen und Literaturen 202. 271-276.

Dobbie, Elliott Van Kirk. 1942. The Anglo-Saxon minor poems. New York: Columbia University Press.

Keefer, Sarah L. 2010. Old English liturgical verse. A student edition. Peterborough, Ont.: Broadview Press.

Klinck, Anne L. 1992. The Old English elegies. A critical edition and genre study. Montreal: McGill-Queen's University Press.

Krapp, George P. 1932. The Paris Psalter and the Meters of Boethius. New York: Columbia University Press.

Kuypers, Arthur B. 1902. The prayer book of Adeluald the bishop, commonly called 'The Book of Cerne'. Cambridge: Cambridge University Press.

Malmberg, Lars. 1979. Resignation. Durham: Durham and St. Andrews Medieval Texts.

Muir, Bernard J. 1994. The Exeter anthology of Old English poetry. Exeter: University of Exeter Press.

Muir, Bernard J. 2006. The Exeter anthology of Old English poetry. Exeter: University of Exeter Press. DVD.

Noronha, Thomas L. 1971. Five Old English verse prayers: An edition. Stanford, Calif.: Stanford University dissertation.

Sweet, Henry. 1883. King Alfred's Orosius. London: Trübner.

Thorpe, Benjamin. 1842. Codex Exoniensis. London: Pickering.

\section{SECONDARY SOURCES}

Banks, Ronald A. 1968. A study of the Old English versions of the Lord's Prayer, the Creeds, the Gloria, and some prayers found in British Museum MS. Cotton Galba A. xiv. London: University of London dissertation.

Bestul, Thomas H. 1977. The Old English Resignation and the Benedictine Reform. Neu-philologische Mitteilungen 78. 18-23.

Bliss, Alan J. and Allen J. Frantzen. 1976. The integrity of Resignation. The Review of English Studies 27. 385-402.

Bloomfield, Morton. 1970. Essays and explorations: Studies in ideas, language, and literature. Cambridge, Mass.: Harvard University Press.

Bosworth, Joseph and Thomas N. Toller. 1898. An Anglo-Saxon dictionary. Oxford: Clarendon.

Brown, Michelle P. 1996. The Book of Cerne: Prayer, patronage and power in ninth-century England. London: British Library; Toronto, Buffalo: University of Toronto Press.

Cameron, Angus, Ashley C. Amos and Antonette diPaolo Healey. 2003. The dictionary of Old English: A to F. Toronto, Ont.: Pontifical Institute of Mediaeval Studies. CD.

Campbell, Alistair. 1959. Old English grammar. Oxford: Clarendon.

Coveney, Dorothy K. 1958. The ruling of the Exeter Book. Scriptorium 12. 51-55.

Förster, Max. 1933. General description of the manuscript. In Raymond Wilson Chambers, Max Förster and Robin Flower. The Exeter Book of Old English poetry. 55-67. London: 
Lund.

Greenfield, Stanley. 1966. A Critical History of Old English Literature. London: University of London Press.

Gretsch, Mechthild. 2008. A context for Resignation A? In Virginia Blanton and Helene Scheck (eds.). Intertexts: studies in Anglo-Saxon culture presented to Paul E. Szarmach, 103117. Tempe, Az.: Arizona Center for Medieval and Renaissance Studies.

Hogg, Richard. 1992. A grammar of Old English, vol. 1. Oxford: Blackwell.

Keefer, Sarah L. 1998. Respect for the book: A reconsideration of 'form', 'content', and 'context' in two vernacular poems. In Sarah L. Keefer and Katherine O’Brien O'Keeffe (eds.). New approaches to editing Old English poetry, 21-44. Woodbridge: Boydell.

Ker, Neil R. 1957. Catalogue of manuscripts containing Anglo-Saxon. Oxford: Clarendon.

Klinck, Anne L. 1987. Resignation: Exile's Lament or Penitent's Prayer?. Neophilologus 71. 423430.

Malone, Kemp. 1930. When did Middle English begin?. Language Monograph 7. 110-117.

Mitchell, Bruce. 1985. Old English syntax. Oxford: Clarendon.

Mora, María. 1995. The invention of the Old English elegy. English Studies 76. 129-139.

Muir, Bernard J. 1989. A preliminary report on a new edition of the Exeter Book. Scriptorium 43. 273-288.

Pickwoad, Nicholas. 2006. Report on the preparation of Exeter D\&C MS 3501 for digitisation. In Bernard James Muir. The Exeter anthology of Old English poetry. Exeter: University of Exeter Press. DVD.

Quirk, Randolph and Charles L. Wrenn. 1955. An Old English grammar. London: Methuen.

Raw, Barbara. 1978. The art and background of Old English poetry. London: Arnold.

Schlauch, Margaret. 1956. English medieval literature and its social foundations. Warszawa: Państwowe Wydawnictwo Naukowe.

Sisam, Kenneth. 1945. Seafarer, lines 97-102. The Review of English Studies 21. 316-317.

Stanley, Eric G. 1955. Old English poetic diction and the interpretation of The Wanderer, The Seafarer and The Penitent's Prayer. Anglia 73. 413-466.

Toller, Thomas N. 1921. An Anglo-Saxon dictionary. Supplement. Oxford: Clarendon.

Whitelock, Dorothy. 1950. The interpretation of The Seafarer. In Cyril Fox and Bruce Dickins (eds.). The early cultures of north-west Europe, 259-272. Cambridge: Cambridge University Press. 